Tamás Bali

\title{
COMPLEX APPROACH TO THE HELICOPTER PILOT'S OPERATIONAL TRAINING
}

DOI: $10.32560 /$ rk.2019.1.12

\begin{abstract}
There are numerous challenges while carrying out rotary wing tasks in the multinational operational environment these days. It is because of the differently used technics, tactics and procedures amongst the participating nations and distinct pilot proficiencies. Operational success requires from all the nations, that their helicopter pilots have adequate operational pilot proficiencies. That kind and level of pilot proficiencies, which provide interoperability. Naturally, NATO standardization agencies cannot ignore this task. They have started the standardization work which is the subject of my study.
\end{abstract}

KEYWORDS: helicopter, helicopter pilot, proficiency, training, rotary-wing tasks

\section{PREFACE}

The NATO Joint Air Power Competence Center (as follows: JAPCC) in Kalkar (Germany), published more than four years ago a document, entitled "Enhancing NATO's Operational Helicopter Capabilities" [1], in which it identified many employment obstacles by analyzing NATO helicopter forces' possibilities and capabilities. These include:

$\downarrow$ differently interpreted rotary wing Tactics, Techniques and Procedures (as follows: TTPs) amongst NATO allied nations, which further fosters the disharmony between the European and American forces,

$\downarrow$ different pilot proficiency level of aircrews, participating in allied missions,

$\rightarrow$ low number of helicopters provided by nations for allied operations,

$\rightarrow$ small number of multinational helicopter trainings and exercises,

$\rightarrow$ compatibility problems on secure voice and data communication between helicopters and helicopters and supported land force subunits,

$\rightarrow$ lack of international courses, focusing on the creation of NATO standard operational planner Command and Control (as follows: C2) abilities,

$\rightarrow$ limited operational experience exchange amongst the allied nations.

Aside of the fact, that the document itself suggested solutions for some of the emerged problems, others still remained unsolved. One of these topics is a required pilot proficiency, which is vital for an efficient and successful allied operational employment. It has been analyzed by NATO Standardization Office's (as follows: NSA) Helicopter Interservice Working Group (as follows: HISWG).

The overall purpose of the work was (and so it is nowadays) to work out a standardized document (accepted by all NATO member nations), which determines the minimum core competencies for aircrews, participating in multinational rotary-wing (as follows: RW) operations. 
The HISWG has worked out the „ATP-90 - Minimum Core Competence levels and Proficiency of Skills for Helicopter Crew for NATO Operations” draft document upon the „Standardization of Qualification for NATO Helicopter Crews in Support of Land Operations" [2] titled document published by JAPCC in July 2015. This document further emphasizes the importance of the standardized operational training for RW aircrews to establish capable interoperability.

\section{HELICOPTER PILOT'S TRAINING AND THEIR PROFICIENCIES}

Helicopter pilot's training - in an ideal situation - constitutes many phases. There must be a phase, which comprises a basic RW pilotage training where any given cadet can learn the basics to control (maneuver) helicopters. This must be followed with a separate basic level operational training phase, where he/she must learn those tactical flying maneuvers which on one hand enables the support of the land forces, on the other hand the self-defense. After getting the basics, specialization comes. Completing this phase, it will allow the individuals to meet the flying requirement concerning their first pilot position.

\section{Helicopter pilot training}

We can recognize this significant separation amongst the phases even in the JAPCC's training structure [2]. The so called „Initial Qualification Training” (as follows: IQT) provides RW pilots with the basic training necessary to qualify for flying duties of a specific airframe without regard to accomplishing any specific missions. It must be underlined, that the IQT provides individuals only with the basic skills necessary to safely operate a specific aircraft but does not include any tactical mission elements. Upon completion of IQT, the aircrew member gets Basic Aircraft Qualification (as follows: BAQ) status. BAQ is a prerequisite for all follow-on trainings.

IQT is followed by the „Mission Qualification Training” (as follows: MQT), which is an advanced pilot training program focusing on the pilotage. The aim of the training phase is to provide adequate level of skills for the given pilots, who are subject to the following operational training phase. At this point Night Vision Googles (as follows: $\mathrm{NVGs}^{1}$ )-, low-level- and Nap of the Earth (as follows: $\mathrm{NOE}^{2}$ ) flying skills must be emphasized along with the proper selfdefense maneuvering with mountainous flight- and Degraded Visual Environment (as follows: DVE) $)^{3}$ flying skills, etc... As a result of the MQT, the helicopter pilot will receive the so called „Basic Mission Capable” license, which leads directly to the operational training phase.

Upon the completion of MQT, operational training can be started, which is called to be as a „Continuation Training” (as follows: CT). During this training phase, all those skills must be

\footnotetext{
${ }^{1}$ NVGs - Night Vision Googles: Two identical monocular optical devices, that amplify existing light by means of an image intensifier and focus it onto a photocathode where it becomes and electronic image which is visible to the eve [10].

${ }^{2}$ NOE - Nap of the Earth: Flight as close to the earth's surface as vegetation or obstacles will permit, while generally following the contours of the earth [8].

${ }^{3}$ Helicopters can operate in adverse weather conditions but the extent to which they can varies based on the aircraft type and operating nation. Helicopters have restrictions for winds, temperatures, visibility and precipitation. For example, degraded visual environments such as fog, rain, dust or snow may prevent or hinder helicopter operations. While low visibility does hinder visual acquisition by the adversary, the helicopter remains vulnerable to radar, laser and thermal-based systems [4].
} 
developed, which are crucial to fly in hostile environment under all circumstances. For this training phase, the given cadets' future helicopter type must be utilized. For instance: In connection with an urban operation training, the one who is supposed to fly transport helicopter in the future perform insertion and extraction, while the other who will fly attack helicopter execute close combat attack ${ }^{4}$.

By cause of the CT successful completion, the helicopter pilot cadet earns the so called „Mission Capable" rating, which facilitates operational employment to the given pilot. Apart from this, the CT can be utilized to regain operational currencies for the pilots who used to have combat ready qualification.

\section{Pilot readiness status}

The Pilot readiness status refers to the actual pilot's operational qualification. It determines whether he has achieved the „Mission Capable” qualification on the field of tactical use of his air asset and has live currencies on the area of operational RW deployment. After all, the range of live currencies represents the pilot readiness status.

We must consider the given helicopter pilot to be „Combat Ready” (as follows: CR) qualified, if he is capable to carry out all of those combat maneuvers, which are allowed by the helicopter design and capabilities, or if he can make do the best of the onboard equipment and maximize the efficiency of weapon employment. When an CR airman is qualified, he can carry out all combat missions assigned to his unit. CR status is obtained after successfully completion of the IQT as well as the required MQT. CR status is sustained by remaining current in all unit tasks and missions.

The given helicopter pilot must be considered as „Deployment Combat Ready” (as follows: DCR) qualified, if he completed IQT and the mission related MQT but qualified only for the mission specific assigned tasks. Apart from this, some of his pilot currencies are not live. For example: If the pilot's NVG currency is expired, he can only be assigned to day Visual Meteorological Condition ${ }^{5}$ (as follows: VMC) flights. Besides, if a helicopter pilot loses his DVE flight currency, he wouldn't be assigned to any of the desert RW operations.

The helicopter pilot must be considered as „Limited Combat Ready” (as follows: LCR), if he completed his IQT and some parts of the MQT. Although, he possesses some live operational currencies, but can be assigned to operational deployment with limitations. It must be noted, that NATO's Joint Air Power Competence Center (as follows: JAPCC) in its recent document [2] does not recognized LCR trained pilot to be an operational ready one.

The last readiness status category is a „Not Combat Ready” (as follows: NCR), which refers to the pilot who is under his pilot training, hasn't completed his IQT and MQT. Evidently doesn't have any operational currencies.

\footnotetext{
${ }^{4}$ Close Combat Attack: An attack by helicopters providing air-to-ground fires for friendly units engaged in close combat as part of the combined arms team. Due to the close proximity of friendly forces, detailed integration between air and ground forces is required. Due to the unique capabilities of aircraft and the enhanced situational awareness of the aircrews, final guidance from ground units or controllers is not necessary [4].

${ }^{5}$ Visual Meteorological Condition is an aviation flight category in which visual flight rules flight is permitted, in which pilots have sufficient visibility to fly the aircraft maintaining visual separation from terrain and other aircraft. https://en.wikipedia.org/wiki/Visual_meteorological_conditions.
} 


\section{THE ROTARY-WING TASKS}

Helicopter related tasks can be grouped in many ways. The main distinction must be made upon the helicopter categories, since we can't expect the same capability from a light scout or trainer, from a medium utility or attack-, or even from a heavy category transport helicopter. Tasks can be examined by their nature also, whether they are carried out in homeland, or abroad as an expeditionary allied operation [3]. Probably the most competent grouping must be based on the operational employment scope of the helicopter categories. To do this, the ATP-49(G) [4] provides an excellent help.

Transport tasks, which - as a collective term - encompasses the widest range of helicopter applicability. Its sub-categories:

1. Air transportation, which stands for the transportation of soldiers, technical assets and different natured supplies. Payload transportation can be executed on-board of a helicopter or/and underslung.

2. Air mobile operations, which grants flexible mobility and quick response ability for land force subunits

3. Airborne missions for helicopters involve the movement of airborne forces and their logistic support into an objective area by air. In airborne operations helicopters are used to deliver land forces and equipment directly onto the objective area by airdrop, which uses parachutes and/or freefall delivery.

4. Aeromedical evacuation (as follows: AE) is the movement of patients under medical supervision by air transport to and between medical treatment facilities as an integral part of the treatment continuum. Although the use of a rotorcraft can decrease transport time, the aeromedical environment creates unique stresses on the injured patient. There are three sub-categories of the AE on doctrinal level [6]. Forward Aeromedical Evacuation is the phase of medical evacuation that provides airlift for patients between point of injury or illness and the initial point of treatment within the area of operations. It is important to underline, that the $\mathrm{AE}$ is carried out in this case in the warzone. Tactical AE provides air transport for patients between medical treatment facilities (as follows: MTFs) within the area of operations. It is conducted by rotary or fixed wing air assets in the joint operational area (as follows: JOA). Strategic AE provides air-transport for patients from MTFs within the area of operations to MTFs outside the area of operations or additional AE between MTFs outside the area of operations. Strategic AE can be done from overseas areas or from theatre of active operations, to the home nation, to other NATO countries or to a temporary out of theatre safe area. It is ultimately a national responsibility. Nevertheless bi- or multi-lateral agreements between nations are an efficient way to share scarce resources of $\mathrm{AE}$ aircraft, equipment and $\mathrm{AE}$ teams. Consideration should be made for the use of civilian charter aircraft for strategic AE provided they can fly into the operational theatre or can operate from an airport in a safe area, within reach of the available tactical AE assets.

Attack tasks, which are covered by armed (attack or scout) helicopters. RWs rapidly apply firepower against the enemy's manpower and technical assets. Helicopters can even restrict the enemy forces' freedom of movement. The attack task's sub-categories are as follows: 
$\neg$ Air Interdiction is an air operation, conducted to divert, disrupt, delay, degrade or destroy an enemy's military potential before it can be brought to bear effectively and at such distance that detailed integration of each air mission with the fire and maneuver of friendly forces is not required.

$\rightarrow$ Close Air Support (as follows: CAS) is an air action against hostile targets which are near (or close) to the friendly forces and which require detailed integration of each air mission with the fire and movement of those forces.

$\rightarrow$ Close Combat Attack (as follows: CCA) is an attack by combat helicopters providing air-to-ground fires for friendly units engaged in close combat as part of the combined arms team. Due to the close proximity of friendly forces, detailed integration between air and ground forces is required. Due to the unique capabilities of aircraft and the enhanced situational awareness of the aircrews, final guidance from ground units or controllers IS NOT necessary. (CCA is not synonymous with CAS!)

Direction and control of fires, which is carried out from the board of the helicopters to direct and control artillery fire, RW and/or FW air asset's fire taking part in any CAS actions. It includes a series of decisions regarding the triggering, observation and correction of fire. Helicopters can quickly maneuver into observation positions that would otherwise be difficult or impossible for ground troops to achieve, greatly increasing the field of view. The direction and control of fires includes:

1. Forward Airborne Air Control is the use of an airborne Forward Air Controller (as follows: FAC) is a proven, effective means to provide CAS to land surface forces.

2. Airborne Artillery Call Fire: Helicopters provide an excellent platform for an Airborne Forward Observer to direct and control the full range of artillery fire.

3. Naval Fire Support: Similarly, during amphibious or littoral operations, Helicopters can direct and control Naval Fires.

Reconnaissance and Tactical Security. Helicopters are excellent airborne surveillance and reconnaissance platforms and can provide commanders timely and accurate information about the adversary and environment. Aircrew with their observation and surveillance sensors (such as electro-optical devices and Forward Looking Infra-Red (FLIR systems), are capable of acquiring information, interpreting, and exploiting it. The three missions in the reconnaissance and tactical security role are:

1. Reconnaissance (as follows: RECCE) is a mission undertaken to obtain, by visual observation or other detection methods, information about the activities and resources of an enemy or potential enemy, or to secure data concerning the meteorological, hydrographic, or geographic characteristics of a particular area.

2. Surveillance is the systematic observation of aerospace, surface or subsurface areas, places, persons, or things, by visual, aural, electronic, photographic, or other means.

3. Tactical Security missions for helicopters are conducted to gather information about adversaries and provide early warning, reaction time, maneuver space and protection for the main body. Tactical security missions include screen, guard, covering force, area security and escort missions.

\section{Specialized tasks}


1. Command Control and Communication Support (as follows: C3 Support) covers a range of tasks, centered on the movement and situational awareness of commanders and the provision of vital communication links in the absence of a fully established ground network. It is divided into three missions: Airborne Command and Control, which is exercised upon the commander's and staff's high mobility need. Helicopters can provide this mobility using their integral radios, allow the commander to maintain situational awareness and communicate with his forces while on the move. It is particularly essential during the urban operations, where flexible $\mathrm{C} 3$ become the key element of success using real time information from the helicopter's board. Command and Control Support is the rapid transport of commanders, staff, and liaison officers to save time in battle procedure and/or to provide commanders with an aerial perspective of their Area of operations. Relay: Helicopters can be employed as communication relay stations and can relay communication messages as well as data. A Helicopter relay station can greatly expand the range over which data can be viewed by ground commanders.

2. Personal Recovery (as follows: PR). PR is the sum of military, diplomatic and civil efforts to affect the recovery and reintegration of isolated personnel. Helicopters are often critical during the execution of PR missions and could take part in all methods of PR. These can be Search and Rescue, Combat Recovery, Combat Search and Rescue and Non-Conventional Assisted Recovery. During any PR operation, transport helicopters carry out search and rescue tasks, while the attack helicopters play important role in supporting them and CCA.

3. Humanitarian aid tasks. Military RWs can be utilized in a wide spectrum for non-military assignments. These can be decisively food and medicament transportation on civil humanitarian organizations request. In general, this is an air activity to help civilians who are not involved in hostilities.

4. Disaster relief tasks, which include all the military RW air activities preventing any natural born or manmade catastrophes or eradicating their negative consequences. In this field, aerial fire-fighting must be underlined as the most commonly used method, which is realized with an underslung carried water balloon, called „Bamby bucket”.

\section{HELICOPTER PILOT QUALIFICATIONS}

The rotary wing arm has a quite of a wide task range which request specialization from the pilots. Let me mention, as a comperative example, the competencies which are needed to the national search and rescue service and to support special operations.

Search and rescue task can be grouped into two main subtask categories: 1. Visual and/or instrument aided search, flown on low and medium level; 2. Rescue procedure, which comprises all of those flying elements, which support the professional activity of the rescue personnel (paramedic, paratrooper) [5].

In contrast, to support special operations, the aircrew must be qualified to fly NOE using NVGs, to perform air interdiction day and night in urban environment, to deploy soldiers using Fast- 
Rope Insertion/Extraction System (as follows: FRIES ${ }^{6}$ ) and Special Patrol Infiltration/Exfiltration System (as follows: $\operatorname{SPIES}^{7}$ ).

To perform the variety of RW tasks in multinational operational environment, NATO's Helicopter Interservice Working Group (as follows: HISWG $^{8}$ ) compiled the „,must” helicopter crew competencies which have to be uniformly mandatory for all participating nations. Using these, all the training phases can be clearly derived, which provide the requested pilot qualifications. From now on, connecting the given pilot (or crew) qualifications with RW tasks, such a matrix can be established, which will accurately define the individual's (or even a crew's) operational readiness status. By the common understanding of this matrix, by adopting and applying all NATO nations involved in NATO operation, we can achieve the goal of having helicopter pilots and aircrews with uniform competencies. However, before introducing an example to the matrix, it is important to define these qualifications:

(Aerial) Combat maneuvering, which is executed in hostile operational environment to avoid and evade threat, posed by RW and FW air assets and surface to air missiles (as follows: MANPADS $^{9}$ ). The efficient combat maneuvering depends on how quickly we can identify the enemy and its weaponry; on the knowledge of enemy's TTPs, combat capabilities and limitations.

Aerial Gunnery qualification. Having this qualification, the aircrew achieve the capability to engage an enemy by using the weapons of an armed helicopter or the weapon systems of an attack helicopter. These can be different caliber machine guns, unguided rockets, guided missiles, aerial bombs. This capability even comprises the effective use of door gunnery.

Qualification to flying in Downgraded Visual Environment (as follows: DVE). We consider the visibility environment to be downgraded, when the pilot's situational awareness therefore the aircraft control cannot be maintained as comprehensively as it is in normal VMC or can even potentially be lost. Under DVE conditions, the helicopter pilot is not able to assess his own spatial situation and to detect stimuli coming from his surroundings. DVE can be caused by smoke, sand, dust, fog, rain, clouds, snow, smog, night due to flat light conditions.

DVE can also be induced by the air asset itself, when the pilot lands or takes off from a dusty or snowy surface.

Device aided night flying qualification. Flights can be executed by intensifying of the ambient lights (moon, stars, earth's surface light sources) and radiated heat by using imaging devices. It must be borne in mind, that due to the constraints of these devices (loss of depth perception, angle of view degradation, reduced visibility of ground reference points) difficulties can be experienced during the training.

\footnotetext{
${ }^{6}$ FRIES - Fast-Rope Insertion/Extraction System: FRIES is a technique for descending a thick rope. It is useful for deploying troops from a helicopter in places where the helicopter itself cannot touch down [11].

${ }^{7}$ SPIES - Special Patrol Infiltration/Exfiltration System: SPIE system was developed as a means to rapidly insert and/or extract a reconnaissance patrol from an area that does not permit a helicopter to land [11].

${ }^{8}$ HISWG - The NATO Helicopter Inter-Service Working Group is part of the NATO Standardization Agency under ACT and works with NATO countries to develop doctrine and TTP's. The most important product from the HISWG is the ATP-49, which concentrates on Army aviation and Air force helicopter operations [1].

${ }^{9}$ MANPADS - Man-portable air-defense systems are shoulder-launched surface-to-air missiles. They are typically guided weapons. https://en.wikipedia.org/wiki/Man-portable_air-defense_system
} 
Qualification to soldiers' insertion and extraction. Although it looks obvious to deploy soldiers by RW air assets with vertical and/or roll-on landing, it is not always possible due to some environmental constrains. These could be for example those confined areas (urban or heavily wooded areas), which limit or even prevent the landing itself. Besides, in some cases the earth surface (such as open water or highly sloped terrain) or the artificial obstacles (like wires) confine the landing. In these cases, alternate insertion/extraction methods must be used to accomplish the given missions. In these situations, the following qualifications are required:

$\rightarrow$ Usage of SPIES. It is a practice of using a system with one end attached to the helicopter and the other end attached to personnel standing on the surface. Personnel can be inserted or extracted from a confined area and transported hanging on the system to a more suitable landing area. SPIE equipment can be a rope, a rope ladder or other (alpine) means.

$\rightarrow$ Another SPIES equipment is the so called „Rope ladder”, which supports multiple soldier insertion and extraction when the aircraft is required to hover at a height that is too high to jump, but low enough that the rope ladder will reach the surface.

$\rightarrow$ Usage FRIES. It is a practice of using one or more ropes at a time with one end attached to the helicopter's hard point allowing soldiers to quickly slide down from the board of a given rotorcraft for insertion to the objective area. The rope has many lanyard loops on it to support quick extraction once soldiers are secured to them.

$\rightarrow$ Hoisting is the practice of using the helicopter's hoist device to lower and retrieve either personnel, stretcher or equipment; which is typically used for rescue operations

$\rightarrow$ Rappel. It is a practice of using rappelling lines attached to the helicopter's hard point to rappel down the assault force to the objective area.

$\rightarrow$ HELO casting, when deploying soldiers into water from the low hover or slow forward flight.

$\downarrow$ Parachute dropping qualification, when soldiers are deployed from the board of a relatively high-flying rotorcraft by having them jumped off the deck.

Low level flying qualification, which enables covert approach to the enemy's position to exploit the advantage of an air raid. There are three main types of RW low level flights: First is a „,normal” low level flight $~ 15$ meters over the ground surface or/and the obstacles; contour flight $\sim 10$ meters over the ground surface or/and the obstacles and the NOE flight which is performed less than 10 meters over the ground surface or/and the obstacles.

Formation flying qualification, which enables effective employment of two or more air assets to accomplish a mission. Formation benefits unity of effort, mutual support and threat detection.

Underslung load carrying qualification. With the capability of swiftly carrying relatively heavy and large loads in the operational area, helicopters provide freedom of movement for the combatant forces. Considering the training aspect - as an effecting factor -, there are three main underslung load types: High density load, which behaves stable while carried (do not tend to swing under the helicopter during the flight); Low density load, which behaves unstable while carried (tend to swing under the helicopter during the flight, the amplitude of swinging depends on the speed, the higher is the flying speed, the swinging amplitude becomes higher and viceversa); The aerodynamic load exhibits both instability and stability which depends on the flying speed (the higher is the flying speed, the swinging amplitude becomes lower and vice-versa). 
Qualification to use water/bamby bucket. To support fire-fighting operations, helicopters can use water/bamby buckets as underslung loads. However special training is required to use the bucket to extinguish fires correctly due to extreme heat and low air pressure conditions. In order to carry out successful fire extinguishing - in addition to the previously mentioned conditions - wind speed and direction must be taken into consideration, flying altitude and speed must be chosen correctly.

Mountainous terrain flight qualification. It is an area, where the changes in terrain elevation exceed 900 meters within a distance of 10 NM [4]. Operating in mountainous terrain requires additional training and knowledge due to degraded helicopter performance and negative environmental conditions like down- and upwashing.

Over-water flying qualification. Due to the wave movements of the open water surface, helicopter pilots can have a spatial disorientation during the rescue operations (especially in hover mode). Heavy winds make situation often even more difficult. Pilot training must concentrate on handling these negative factors.

Qualification to operate under $\mathbf{C B R} \mathbf{N}^{10)}$ conditions. Nowadays, NATO forces are likely to encounter CBRN environments when operation in hostile environment. RW pilots must be capable to handle these effects, to use their personal protective gears, to fly under the psychic stress load.

Instrument flying, when flights cannot be carried out under visual meteorological conditions due to low visibility or ceiling.

\section{MATRIX OF RW TASKS AND HELICOPTER PILOT QUALIFICATIONS}

Having been defined the RW tasks and all the qualifications which are requested for their completion, a comprehensive matrix-like table can be drawn.

Assessing this matrix, it becomes obvious for each of the commanders which given individual or aircrew can be assigned to specific tasks. Moreover, this matrix provides guideline in standardizing training requirements for NATO helicopter crews in support of land operations.

However, the determination of the requested pilot qualification could be a bit faded by the fact, that it is not always clear that a certain qualification for a given task mandatory or just recommended. Likewise, current operational needs and environmental conditions must be also taken into consideration in order to determine the need for any pilot qualifications. As an example: Whether the NOE qualification is required for an air transportation to mitigate threat or is it only recommended due to the proper reconnaissance support in the given operational area? Remaining on air transportation: mountain flying qualifications cannot always be mandatory to perform it, since it is unlikely that we always fly at mountainous terrain.

Table 1 illustrates an example of some elements of the above explained matrix. In order to interpret the matrix, as follows the letters explanations: $\mathrm{X}=$ Must to have a qualification; $\mathrm{A}=$ Qualification is advisable; $\mathrm{D}=$ The need for a qualification depends on the nature of a given task; $\mathrm{O}=$ The need for a qualification depends on the operational environment; - = No need for the qualification.

\footnotetext{
${ }^{10} \mathrm{CBRN}$ - Chemical, biological, radiological and nuclear: A collective term used only when referring to a combined chemical, biological, radiological and nuclear operation [9].
} 


\begin{tabular}{|c|c|c|c|c|c|c|c|c|c|c|c|c|c|c|c|c|c|c|c|c|c|c|}
\hline \multirow[b]{3}{*}{ TASKS } & \multicolumn{22}{|c|}{ HELICOPTER PILOT QUALIFICATIONS } \\
\hline & \multicolumn{3}{|c|}{ Combat maneuvering } & \multirow[b]{2}{*}{ 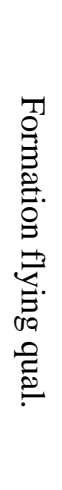 } & \multicolumn{3}{|c|}{ Low level flying } & \multicolumn{2}{|c|}{$\begin{array}{l}\text { Underslung } \\
\text { load carry }\end{array}$} & \multirow[b]{2}{*}{ 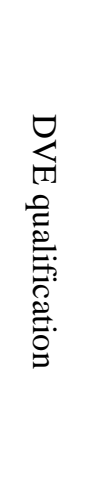 } & \multirow[b]{2}{*}{ 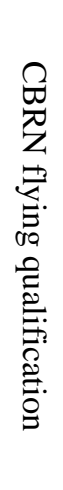 } & \multirow{2}{*}{ 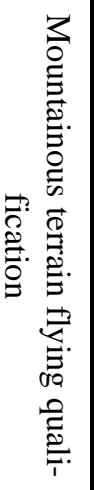 } & \multirow[b]{2}{*}{ 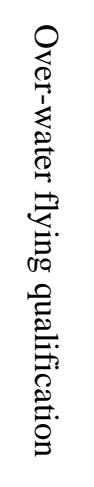 } & \multirow[b]{2}{*}{ 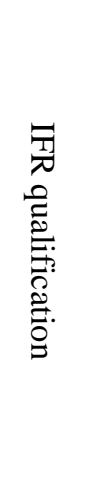 } & \multirow{2}{*}{ 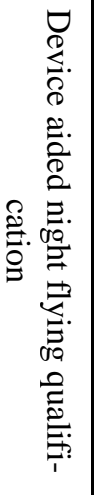 } & \multicolumn{6}{|c|}{ Insertion and extraction } & \multirow[b]{2}{*}{ 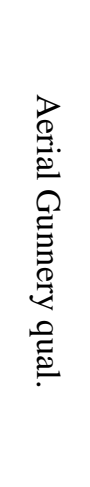 } \\
\hline & 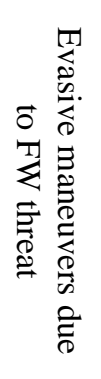 & 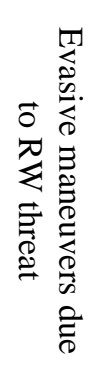 & 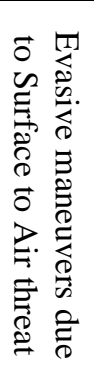 & & 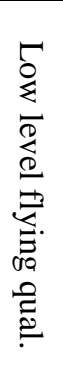 & 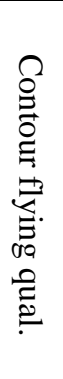 & $\begin{array}{l}Z \\
0 \\
0 \\
\text { 11 } \\
0 \\
\stackrel{\tilde{g}}{0}\end{array}$ & 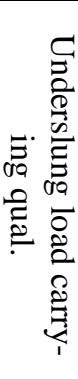 & 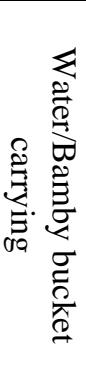 & & & & & & & 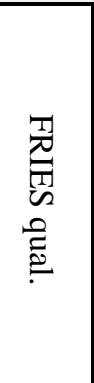 & 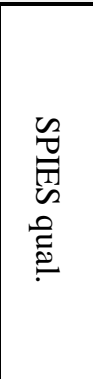 & 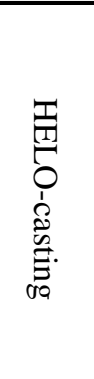 & 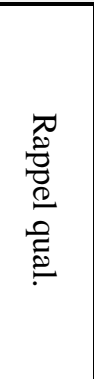 & 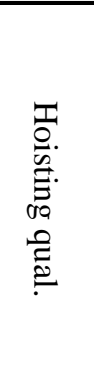 & 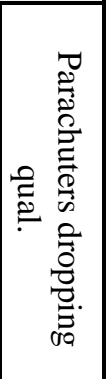 & \\
\hline \multicolumn{23}{|l|}{ Transport tasks } \\
\hline Air transportation & $\mathrm{D}$ & $\mathrm{D}$ & A & $\mathrm{X}$ & $\mathrm{D}$ & - & - & $\mathrm{D}$ & - & - & $\mathrm{O}$ & $\mathrm{D} / \mathrm{O}$ & $\mathrm{D}$ & - & A & - & - & - & - & - & - & $\mathrm{D} / \mathrm{A}$ \\
\hline $\begin{array}{l}\text { Air Mobile opera- } \\
\text { tions }\end{array}$ & $\mathrm{D}$ & $\mathrm{D}$ & $\mathrm{X}$ & $\mathrm{X}$ & $\mathrm{X}$ & $\mathrm{X}$ & $\mathrm{X}$ & $\mathrm{D} / \mathrm{A}$ & - & $X$ & $\mathrm{O}$ & $\mathrm{D} / \mathrm{O}$ & $\mathrm{D} / \mathrm{O}$ & $\mathrm{K} / \mathrm{A}$ & $X$ & $\mathrm{D} / \mathrm{A}$ & $\mathrm{D} / \mathrm{A}$ & $\mathrm{D} / \mathrm{A}$ & $\mathrm{D} / \mathrm{A}$ & $\mathrm{D} / \mathrm{A}$ & $\mathrm{D} / \mathrm{A}$ & $\mathrm{X}$ \\
\hline AIREVAC & $\mathrm{D}$ & $\mathrm{D}$ & $X$ & $X$ & $X$ & $\mathrm{X}$ & $\mathrm{D} / \mathrm{A}$ & - & - & $\mathrm{O} / \mathrm{A}$ & $\mathrm{O}$ & $\mathrm{D} / \mathrm{O}$ & $\mathrm{D} / \mathrm{O}$ & $\mathrm{O} / \mathrm{A}$ & $\mathrm{D} / \mathrm{A}$ & - & - & - & $\mathrm{D} / \mathrm{A}$ & A & - & $\mathrm{D}$ \\
\hline \multicolumn{23}{|l|}{ Attack tasks } \\
\hline Air interdiction & $\mathrm{D} / \mathrm{A}$ & $\mathrm{D} / \mathrm{A}$ & $X$ & $\mathrm{X}$ & $\mathrm{X}$ & $\mathrm{X}$ & $\mathrm{X}$ & - & - & - & $\mathrm{O}$ & $\mathrm{D} / \mathrm{O}$ & $\mathrm{D} / \mathrm{O}$ & $\mathrm{O} / \mathrm{A}$ & $\mathrm{X}$ & - & - & - & - & - & - & $\mathrm{X}$ \\
\hline CAS & $\mathrm{D} / \mathrm{A}$ & $\mathrm{D} / \mathrm{A}$ & $X$ & $X$ & $X$ & $\mathrm{X}$ & $X$ & - & - & - & $\mathrm{O}$ & $\mathrm{D} / \mathrm{O}$ & $\mathrm{D} / \mathrm{O}$ & $\mathrm{O} / \mathrm{A}$ & $X$ & - & - & - & - & - & - & $X$ \\
\hline $\mathrm{CCA}$ & $\mathrm{D} / \mathrm{A}$ & $\mathrm{D} / \mathrm{A}$ & $X$ & $X$ & $\mathrm{X}$ & $X$ & $X$ & - & - & - & $\mathrm{O}$ & $\mathrm{D} / \mathrm{O}$ & $\mathrm{D} / \mathrm{O}$ & $\mathrm{O} / \mathrm{A}$ & $\mathrm{D} / \mathrm{A}$ & - & - & - & - & - & - & $X$ \\
\hline \multicolumn{23}{|c|}{ Direction and Control of fires } \\
\hline $\begin{array}{l}\text { Forward Air Con- } \\
\text { trol }\end{array}$ & $\mathrm{D}$ & $\mathrm{D}$ & $\mathrm{X}$ & - & $X$ & $X$ & $X$ & - & - & - & $\mathrm{O}$ & $\mathrm{D} / \mathrm{O}$ & $\mathrm{D} / \mathrm{O}$ & A & $X$ & - & - & - & - & - & - & $\mathrm{X}$ \\
\hline $\begin{array}{l}\text { Artillery call for } \\
\text { fire }\end{array}$ & $\mathrm{D}$ & $\mathrm{D}$ & $\mathrm{X}$ & - & $\mathrm{X}$ & $\mathrm{X}$ & $\mathrm{X}$ & - & - & - & $\mathrm{O}$ & $\mathrm{D} / \mathrm{O}$ & - & A & $\mathrm{D} / \mathrm{A}$ & - & - & - & - & - & - & $\mathrm{X}$ \\
\hline
\end{tabular}




\begin{tabular}{|l|c|c|c|c|c|c|c|c|c|c|c|c|c|c|c|c|c|c|c|c|c|c|}
\hline Airborne reconnaissance \\
\hline Reconnaissance & $\mathrm{D} / \mathrm{A}$ & $\mathrm{D} / \mathrm{A}$ & $\mathrm{X}$ & - & $\mathrm{X}$ & $\mathrm{X}$ & $\mathrm{X}$ & - & - & - & $\mathrm{O}$ & $\mathrm{D} / \mathrm{O}$ & $\mathrm{D} / \mathrm{O}$ & $\mathrm{A}$ & $\mathrm{X}$ & - & - & - & - & - & - & $\mathrm{X}$ \\
\hline Surveillance & $\mathrm{D} / \mathrm{A}$ & $\mathrm{D} / \mathrm{A}$ & $\mathrm{X}$ & - & $\mathrm{X}$ & $\mathrm{X}$ & $\mathrm{X}$ & - & - & - & $\mathrm{O}$ & $\mathrm{D} / \mathrm{O}$ & $\mathrm{D} / \mathrm{O}$ & $\mathrm{A}$ & $\mathrm{X}$ & - & - & - & - & - & - & $\mathrm{X}$ \\
\hline Tactical security & $\mathrm{D} / \mathrm{A}$ & $\mathrm{D} / \mathrm{A}$ & $\mathrm{X}$ & - & $\mathrm{X}$ & $\mathrm{X}$ & $\mathrm{X}$ & - & - & $\mathrm{D} / \mathrm{A}$ & $\mathrm{O}$ & $\mathrm{D} / \mathrm{O}$ & $\mathrm{D} / \mathrm{O}$ & $\mathrm{A}$ & $\mathrm{X}$ & $\mathrm{D}$ & - & - & $\mathrm{D}$ & $\mathrm{D}$ & - & $\mathrm{X}$ \\
\hline Specialized tasks \\
\hline $\begin{array}{l}\text { Personal recov- } \\
\text { ery }\end{array}$ & $\mathrm{D}$ & $\mathrm{D}$ & $\mathrm{X}$ & $\mathrm{X}$ & $\mathrm{X}$ & $\mathrm{X}$ & $\mathrm{X}$ & - & - & $\mathrm{O} / \mathrm{A}$ & $\mathrm{O}$ & $\mathrm{D} / \mathrm{O}$ & $\mathrm{D} / \mathrm{O}$ & $\mathrm{A}$ & $\mathrm{X}$ & $\mathrm{A}$ & $\mathrm{A}$ & $\mathrm{A}$ & $\mathrm{A}$ & $\mathrm{A}$ & $\mathrm{A}$ & $\mathrm{X}$ \\
\hline CR & $\mathrm{D}$ & $\mathrm{D}$ & $\mathrm{X}$ & $\mathrm{X}$ & $\mathrm{X}$ & $\mathrm{X}$ & $\mathrm{X}$ & $\mathrm{D}$ & - & $\mathrm{X}$ & $\mathrm{O}$ & $\mathrm{D} / \mathrm{O}$ & $\mathrm{D} / \mathrm{O}$ & $\mathrm{X}$ & $\mathrm{X}$ & $\mathrm{X}$ & $\mathrm{X}$ & $\mathrm{D} / \mathrm{A}$ & $\mathrm{X}$ & $\mathrm{X}$ & $\mathrm{A}$ & $\mathrm{X}$ \\
\hline CSAR & - & - & - & - & - & - & - & - & - & $\mathrm{X}$ & $\mathrm{O}$ & $\mathrm{D} / \mathrm{O}$ & $\mathrm{D} / \mathrm{O}$ & $\mathrm{X}$ & $\mathrm{D} / \mathrm{A}$ & - & - & $\mathrm{A}$ & $\mathrm{A}$ & $\mathrm{X}$ & $\mathrm{A}$ & - \\
\hline SAR & - & - & - & - & - & - & - & $\mathrm{X}$ & $\mathrm{X}$ & $\mathrm{O} / \mathrm{A}$ & - & $\mathrm{D} / \mathrm{O}$ & - & - & - & - & - & - & - & - & - & - \\
\hline Disaster relief
\end{tabular}

Table 1. Example of some elements of the matrix of RW tasks and helicopter pilot qualifications [2]. 
Although, this matrix can provide clear picture for each of the nations, but the common understanding is shaded by the different interpretation. Even the nations accept JAPCC's recommendations, the core of the problem is, that there is no consensus amongst the nation on task related helicopter pilot qualifications. While some of the nation allocates not more than one or two pilot qualifications to a given task, others evaluate the need for nearly all of them. It is obvious for the „others”, that all operational aspects and possibilities must be taken into consideration and evidently all their pilots must always be maximally qualified for each of these tasks.

During a Medevac mission, formation flying qualification can be considered as a „must”, since attack helicopters are flying along with the transport helicopters to provide defense for them. On the other hand, formation flying qualification at Medevac can be considered as a ,not necessary” one, since it isn't carried out at a high threat level. So, transport helicopters can perform that as a standalone asset [6]. If there is a significant hostile activity in the vicinity of the rescue area, that task is not a Medevac anymore but a Combat Recovery [7]. Likewise, while combat maneuvering qualification is a must for some nations for airborne reconnaissance, for the others it is just advisable. The difference in views can also be reflected with the fact, that to the sixth version of the qualification matrix which was submitted to Hungary in December 2016, we had 61 amendments.

The dissonance described above predicts, that matrix work out will continue for a long time, and probably no consensus will arise. The NSA will surely release a Stanag, which will most likely reflect the majority's view. In response, the nations belonging to the minority will probably implement this Stanag with premises (if they implement it at all). This dilemma thus leads back to the core problem, that there will be again a large discrepancy in the area of pilot and aircrew operational qualifications amongst the nations.

The situation can be further tinkered by two things. One is the content of the qualification, the other is the frequency of the flights required to maintain the qualification. The problem with the content of the qualification might be best clarified through an example. We must understand, that it is far from the same at the mountain flight qualification if its training is done at 1,000 or at 4,000 meters. The pilots can have the same qualifications (on paper) but again their skills are far from the same. Similar differences may arise for example with regard to DVE or even to the formation flying qualifications. Likewise, in the absence of any common (doctrinal level) regulation, nations tend to differ on the field of the frequency of flights connected to any given qualification. Some maintains IFR qualification with 30 days/flight-, others with 3 months/flight recurrences. It is also obvious, that we don't get the same level of skill, if the helicopter pilot performs brown-out flights in every 30 days, or just with a 180 days/flight repetition.

Although, it is obvious, that the nations' budgetary constraints have negative impact on the amount of the flying hours used to maintain competent pilot skills and qualifications and on the density of mandatory checks flights required to maintain the given skills, there must be an alliance level accepted compromised solution on this field as well. 


\section{CONCLUSION}

The execution of allied RW missions requires a common understanding of pilot qualifications from the participating nations, moreover an equal level of skills from the actual pilots. To achieve this interoperability goal, NATO NSA HISWG has developed a relevant document as a result of its cooperation with the JAPCC. The nations could express their opinion on the document using the so called "silent procedure".

The elaboration of the document brought many disagreements to the surface, which, although slowed down the activity, did not change its orientation. So far, and thereafter, the "Working Group Forum" interface on the NSA website allows for national suggestions, comments and possible modifications in an interactive way.

The end state will be a Stanag issue, which will provide precise guidance on the skills required for the allied operations, the system of maintaining pilot skills and qualifications. With this, the commanders' resource management will become easier, the pace of operation will increase, as a result of which the capability of initiation remains on NATO's side.

\section{BIBLIOGRAPHY}

[1] Enhancing NATO's operational helicopter capabilities (Published by: JAPCC, Published in: August 2012., Downloaded from and time: https://www.japcc.org/portfolio/enhancing-natos-operational-helicopter-capability/, 22. January 2017. 14:37),

[2] Standardization of qualification for NATO helicopter crews in support of land operations (Published by: JAPCC, Published in: July 2015., Downloaded from and time: https://www.japcc.org/portfolio/standardization-qualifications-nato-helicopter-crews-support-land-operations/, 14 January 2017. 21:38),

[3] T. Bali: Helikoptervezetők müveleti feladatokra történő képzésének szövetségesi megközelítése, Repüléstudományi Közlemények, XXIX. évfolyam, 2017/2. szám, 53., http://www.repulestudomany.hu/folyoirat/2017_2_index.html

[4] ATP-49 Edition G Version 1 Use of Helicopter in Land Operations (Publisher: NATO Standardization Office, Published in: April 2015.),

[5] ATP-10(D) Search and Rescue (Publisher: NATO Standardization Office, Brussels /Bel/, Published in: 10 January 1995),

[6] AJP-4.10(B) Edition B Allied Joint Doctrine for Medical Support (Publisher: NATO Standardization Office, Brussels /Bel/, Published in: May 2015),

[7] BI-SC Joint Operational Guidelines 11/01 Joint Personnel Recovery, (Publisher: NATO Allied Command Transformation, Published in: 28 January 2011),

[8] Aircrew Training Requirements for Nap of the Earth flights, (Publisher: US. Army Research Institute for the Behavioral and Social Sciences, Published in: August 1976)

[9] AAP-6 NATO Glossary of Terms and Definitions. (Publisher: NATO Standardization Office, Brussels /Bel/, Published in: 12 January 2016.)

[10] Night Vision and Night Vision Goggles (Publisher: USAF Air War Collage, Published in: 1990)

[11] MCRP 3-114A Helicopter Rope Suspension Techniques Operations (Publisher: US Marine Corps: Published in: 13 August 2013) 


\section{A HELIKOPTERVEZETÖK KIKÉPZÉSÉNEK KOMPLEX MEGKÖZELÍTÉSE}

A többnemzeti környezetben teljesitett katonai forgószárnyas feladatok végrehajtásai több esetben nehézségekbe ütköztek a benne résztvevő nemzetek eltérö harcászati felfogásai, illetve a gépszemélyzetek különbözö repülési jártasságainak okán. A müveleti siker megkivánja azt, hogy a benne résztvevö helikoptervezetök rendelkezzenek az elvárt müveleti repülési képesitésekkel. Olyan szintü és jellegü képesitésekkel, melyek biztositják a zökkenömentes interoperabilitást. Természetszerüleg a NATO szabványositási feladatait ellátó szervezetek sem mehetnek el e feladat mellett. Megkezdödött a témával kapcsolatos kidolgozói munka, melynek részleteivel foglalkozik tanulmányom.

Kulcsszavak: helikopter, helikoptervezetö, képzettség, kiképzés, forgószárnyas feladatok

Dr. Bali Tamás ezredes

Bázisparancsnok helyettes

MH 86. Szolnok Helikopter Bázis

bali.tamas@hm.gov.hu

orcid.org/0000-0001-6098-8602
Col. Tamás Bali Ph.D.

Deputy base commander

HDF 86th Szolnok Helicopter Base

bali.tamas@hm.gov.hu

orcid.org/0000-0001-6098-8602

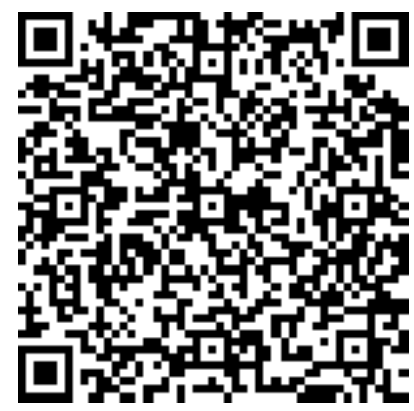

http://journals.uni-nke.hu/index.php/reptudkoz/article/view/87/41 